DOI: 10.19085/journal.sijmas031201

\title{
An Assessment of Drinking Water Quality in Cauvery Delta Region and Palar Region, Tamil Nadu
}

\author{
R. Sophia Porchelvi \\ Associate Professor of Mathematics, A.D.M College for Women (Autonomous), Nagapattinam, India. \\ P.Selvavathi \\ Research Scholar, Department of Mathematics, A.D.M College for Women (Autonomous), Nagapattinam, \\ India.
}

oScholedge International Journal of Multidisciplinary \& Allied Studies (ISSN 2394-336X), Vol.03, Issue 12 (2016) pg238-254. Published by: Scholedge R\&D Center [www.theSCHOLEDGE.org] [Email: editorial@thescholedge.org]

\begin{abstract}
Delta regions of the Cauvery River basin are one of the significant areas of rice production in India. In spite of large-scale utilization of the river basin for irrigation and drinking purposes, the lack of appropriate water management has seemingly deteriorated the water quality due to increasing anthropogenic activities. Vellore is the second most populous district of Tamil Nadu in India where the Palar River flowing towards east for about $295 \mathrm{Km}$. Vellore is surrounded by many leather tanneries and small scale dying industries and their effluents are discharged into the Palar river causing impact on the quality of the underground water. To assess the extent of deterioration, physicochemical characteristics of surface water were analyzed select regions of Cauvery Delta River basin and Palar region, Tamil Nadu, during March 2016 to May 2016. This study aimed to examine quality of drinking groundwater. The results represented whether the water was suitable or unsuitable for drinking purposes in this area. It was also observed that some areas like Tiruvarur, Needamangalam, Kamalapuram, Arcot, Soraiyur, Ranipet had low quality drinking water. It is suggested to take some necessary measures for supplying desirable water to the people living in these areas.
\end{abstract}

Key words: Cauvery delta region, Palar region, water quality, physicochemical parameters

\section{Introduction}

Water is an essential resource for all life on the planet. Presently there is only $1 \%$ water which is drinkable on our planet where as our planet is covered with water by $70 \%$, which is salt water and not usable for human. Very soon we all are going to face complex and urgent water problems and the only way to create a healthier future is for everyone to do their part to save rivers from pollution. Whole Indian population is directly or indirectly depends upon these rives either these are big national level rivers or small rivers like Ganga, Yamuna, Narmada, Cauvery, Palar etc. but sadly these all rivers face pollution from many sources: farming, industry and even tourism.

Water pollution is a leading cause of death. It causes many a death every day. Facilities to treat waste water are not adequate in any city in Tamil Nadu. At present, only a very small portion of waste water is treated. The rest is discharged into our water bodies. Owing to this, pollutants enter groundwater, rivers and other water bodies. Such water, which ultimately ends up in our households, is often highly contaminated and carries disease-causing microbes. Agricultural runoff, or the water from the fields that drains into rivers, is another major water pollutant as it contains fertilisers and pesticides.

Delta regions of the Cauvery River basin are one of the significant areas of rice production in India. In spite of large-scale utilization of the river basin for irrigation and drinking purposes, the lack of appropriate water management has seemingly deteriorated the water quality due to increasing anthropogenic activities. 
In the past 30 years, the ONGC was exploring oil and natural gas in the Cauvery Basin but its activities had spoiled the groundwater and other precious natural resources affecting farmers in a massive manner. Previously to explore crude oil, the ONGC was sinking wells to a depth of 500 to 1,000 feet but the depths of the new wells have sunk to $3.5 \mathrm{~km}$ now, speakers alleged adding that the chemical fracturing resorted to by the ONGC was spoiling the ecology of the zone.

The Cauvery delta coal-bed methane extraction project is currently undertaken by Great Eastern Energy Corporation Ltd (GEECL), a private company based in Gurgaon, Haryana. The project aims to extract methane gas from coal-bed using hydraulic fracturing method of hydraulic fracturing in the Cauvery river basin. The company received licence to explore and extract CBM from Nagapattinam, Thanjavur and Thiruvarur districts which are the major rice cultivating area of Tamil Nadu. Farmers, environmentalist and experts are opposing the project and hence it is currently suspended by the Government of Tamil Nadu. They demanded that to protect the Cauvery basin in the delta region and to preserve the livelihood of the lakhs of farmers and farmer workers, the ONGC must be forced to leave the region by declaring the Cauvery delta as protected agriculture zone.

Vellore is the second most populous district of Tamil Nadu in India where the Palar River flowing towards east for about $295 \mathrm{Km}$. The river sets as the major water source recharging the ground water nearby areas. Vellore is surrounded by many leather tanneries and small scale dying industries and their effluents are discharged into the Palar river causing impact on the quality of the underground water. Many industries have a need to treat water to obtain very high quality water for demanding purposes such as environmental discharge compliance. Factories are expected to treat its effluent wastes prior to discharge. Toxic material must be treated chemically and converted into harmless materials. If possible, factories should try to recycle the treated water.

Now it becomes important to protect the ground water from pollution in order to save the water quality for our ourselves and future generations. Hence, it becomes necessary to study the quality of the groundwater of the Cauvery delta region and Palar region.

\section{Experimental}

\subsection{Study Areas}

The present investigation was carried out on Tiruvarur, Thanjavur and Nagapattinam town and their adjacent areas in the Cauvery Delta region and Palar region in vellore district in Tamil Nadu.

Table 1(a): Sampling Points of Cauvery delta region

\begin{tabular}{|c|c|}
\hline Sampling places & Sampling Point number \\
\hline Nagore & $\mathrm{S}_{1}$ \\
\hline Nagapattinam & $\mathrm{S}_{2}$ \\
\hline Kizhvelur & $\mathrm{S}_{3}$ \\
\hline Adiyakamangalam & $\mathrm{S}_{4}$ \\
\hline Tiruvarur & $\mathrm{S}_{5}$ \\
\hline Koradacherry & $\mathrm{S}_{6}$ \\
\hline
\end{tabular}




\begin{tabular}{|c|c|}
\hline Needamangalam & $\mathrm{S}_{7}$ \\
\hline Kamalapuram & $\mathrm{S}_{8}$ \\
\hline Thirumakottai & $\mathrm{S}_{9}$ \\
\hline Thanjavur & $\mathrm{S}_{10}$ \\
\hline
\end{tabular}

Table 1(b): Sampling Points of Palar region

\begin{tabular}{|c|c|}
\hline Sampling places & Sampling Point number \\
\hline Arcot & $\mathrm{S}_{1}$ \\
\hline Soraiyur & $\mathrm{S}_{2}$ \\
\hline Ranipet & $\mathrm{S}_{3}$ \\
\hline
\end{tabular}

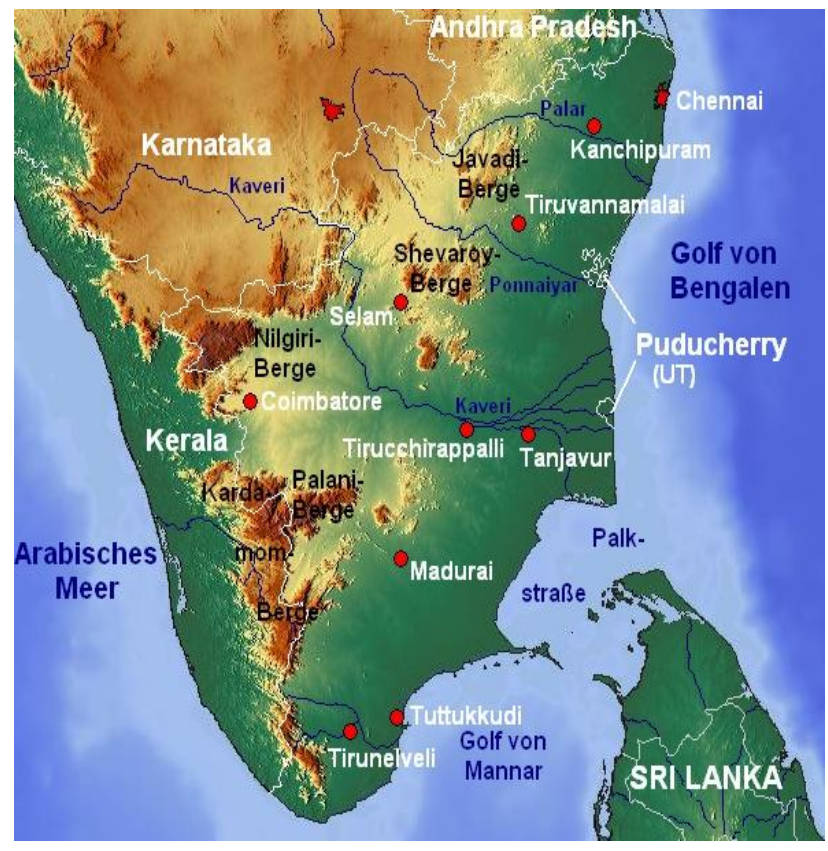

Figure shows the location of the drinking water samples collected

\subsection{Methodology}

This study was conducted to assess the quality of drinking water in cauvery delta region with Palar region in Tamil Nadu. Ten water samples were collected from cauvery delta region and three samples were collected in Palar region and also analyzed the physicochemical parameters in Tamil Nadu Agricultural University, Coimbatore. The concentrations of the physicochemical parameters are discussed below. 


\section{Results and Discussions}

The water samples were collected from various parts of Cauvery delta region and Palar region, and were analyzed for their physicochemical characteristics. The odour and taste of the samples were noted at the collection point immediately.

The other physical parameters such as turbidity, electrical conductivity and total dissolved solids were determined by standard procedures. The $\mathrm{pH}$ of the water samples was measured using $\mathrm{pH}$ meter. The chemical parameters like chloride, calcium hardness, magnesium, iron, nitrate, nitrite, sulphate, manganese, zinc, phosphate, copper and heavy metals like lead were estimated by various method ( table 1). The results were compared with B1Sdrinking water quality guideline. The estimated physicochemical parameters are reported in the Table number 3 and 4.

Table 2: Methods used for estimation of various physicochemical parameters

\begin{tabular}{|l|l|l|}
\hline Parameters & Method & Reference \\
\hline $\mathrm{pH}$ & $\mathrm{pH}$-metric & IS:3025 (Part II) \\
\hline Taste & Taste Rating & IS:3025 (Part 8) \\
\hline Odour & Olfactory method & IS:3025 (Part 5) \\
\hline Turbidity & Nephelo metric method & \\
\hline Electrical Conductivity & Conduct metric & IS:3025 (Part 10) \\
\hline Total Dissolved Solid & Gravimetric method & IS:3025 (Part 16) \\
\hline Chloride & Argento metric method & \\
\hline & & IS:3025 (Part 24) \\
\hline & & \\
\hline & & \\
\hline & & \\
\hline & & \\
\hline
\end{tabular}




\begin{tabular}{|c|c|c|}
\hline Calcium & EDTA Titrimetric method & IS : 3025 (Part 40) \\
\hline Magnesium & EDTA Titrimetric method & IS : 3025 (Part 46) \\
\hline Manganese & Colour comparison & IS $3025: 1964$ \\
\hline Nitrate & Chromo tropic acid method & IS : 3025 (Part 34) \\
\hline Iron & 1,10-Phenanthroline method & IS : 3025 (Part 53) \\
\hline Nitrite & Spectrophotometric method & IS : 3025 (Part 34) \\
\hline Copper & Neocuprine method & IS : 3025 (Part 42) \\
\hline Phosphate & Spectrophotometric method & IS $3025: 1964$ \\
\hline Zinc & Spectrophotometric method & IS $3025: 1964$ \\
\hline Lead & Spectrophotometric method & IS $3025: 1964$ \\
\hline
\end{tabular}

\subsection{Discussions of the physicochemical parameters in the study area}

\section{Taste and odour}

The primary sources of taste and odour problems in drinking water are algae and bacteria. Man-made chemicals are another source of taste and odour-causing chemicals in drinking water. However, other anthropogenic sources such as wastewater discharges, industrial phenols and chemical spills also act as sources of chemicals that cause off tastes and odours. Such chemicals can affect both groundwater and surface water. However, all the ground water samples having agreeable odour and in Cauvery delta region Nagore, Kilvelur, Tiruvarur, Kamalapuram, Thirumakkottai samples had the salty taste. High levels of naturally occurring magnesium may cause a salty taste. 


\section{Electrical Conductivity}

Electrical conductivity is the capacity of water to convey current and this may be due the presence of soluble salts and ionic species which act as conducting medium. Conductivity of samples from Cauvery delta region and Palar region range between $(0.58-4.84) \mathrm{dsm}^{-1}$ and $(0.50-1.70) \mathrm{dsm}^{-1}$ respectively (Table 3 and 5)

\section{Total dissolved solids}

Total dissolved solids (TDS) is the term used to describe the inorganic salts and small amounts of organic matter present in solution in water. Water containing TDS concentrations below $1000 \mathrm{mg} /$ litre is usually acceptable to consumers, although acceptability may vary according to circumstances. However, the presence of high levels of TDS in water may be objectionable to consumers owing to the resulting taste and to excessive scaling in water pipes, heaters, boilers, and household appliances. The TDS of ground water sample number $\mathrm{S}_{1}$ (Nagore) is high in the Cauvery delta region and $\mathrm{S}_{3}$ (Ranipet) in Palar region, (Table 3)

\section{Turbidity}

Turbidity is a measure of the relative clarity of water. Turbidity values above 5 NTU become perceptible to the eye, especially in large volumes such as a white sink or bath. The turbidity range of the Cauvery delta region is $(0.7-1.2)$ NTU and Palar region is $(0.6-1.4)$ NTU.

\section{Hydrogen ion concentration $(\mathrm{pH})$}

The $\mathrm{pH}$ of water is a measure of the acid-base equilibrium and, in most natural waters, is controlled by the carbon dioxide-bicarbonate-carbonate equilibrium system. An increased carbon dioxide concentration will therefore lower $\mathrm{pH}$, whereas a decrease will cause it to rise. Exposure to extreme $\mathrm{pH}$ values results in irritation to the eyes, skin, and mucous membranes. Eye irritation and exacerbation of skin disorders have been associated with pH values greater than 11. Below pH 4, redness and irritation of the eyes have been reported, the severity of which increases with decreasing $\mathrm{pH}$. The $\mathrm{p}^{\mathrm{H}}$ of the ground water sample in Cauvery delta region ranges from $6.93-7.93$ and in Palar region ranges from $5.26-8.02$. These two region $\mathrm{p}^{\mathrm{H}}$ value lies in the BIS Desirable limit $(6.5-8.5)$.

\section{Chloride}

Chlorides are leached from various rocks into soil and water by weathering. The chloride ion is highly mobile and is transported to closed basins or oceans. Chloride increases the electrical conductivity of water and thus increases its corrosivity. In metal pipes, chloride reacts with metal ions to form soluble salts (8), thus increasing levels of metals in drinking-water. In lead pipes, a protective oxide layer is built up, but chloride enhances galvanic corrosion (14). It can also increase the rate of pitting corrosion of metal pipes (8). Chloride concentrations in excess of about $250 \mathrm{mg} /$ litre can give rise to detectable taste in water, but the threshold depends upon the associated cations. The chloride content estimated in the samples in Cauvery delta region ranged between $25 \mathrm{mg} / \mathrm{l}-313.24 \mathrm{mg} / \mathrm{l}$ and in Palar region ranged between $20 \mathrm{mg} / \mathrm{l}-$ $48 \mathrm{mg} / \mathrm{l}$ (Table 4), (Fig. 8).

\section{Sulphate}

Sulphate may be leached from the soil and is commonly found in most water supplies. Diarrhea and dehydration are often observed when individuals accustomed to drinking water

with low concentrations of sulphate consume water with high amounts of sulphate. It is not advisable to use water that contains high concentrations of sulphate for infant feeding. The sulphate level of the samples in Cauvery delta region ranged between $1.6 \mathrm{mg} / \mathrm{l}-35 \mathrm{mg} / \mathrm{l}$ and in Palar region ranged between $10.30 \mathrm{mg} / \mathrm{l}-28 \mathrm{mg} / \mathrm{l}$ (Table 4), (Fig. 8). 


\section{Calcium}

The presence of calcium ions in the water makes it hard. Soft water readily forms lather with soap, but it is more difficult to form lather with hard water. The dissolved calcium ions in hard water react with the soap to form scum, so more soap is needed. The calcium concentration was recorded in $43.1 \mathrm{mg} / \mathrm{l}-138.28 \mathrm{mg} / \mathrm{l}$ of Cauvery delta region and in $62 \mathrm{mg} / \mathrm{l}-187 \mathrm{mg} / \mathrm{l}$ of Palar region, (Table 4), (Fig 6).

\section{Magnesium}

The presence of magnesium ions in the water makes it hard. The Magnesium hardness was recorded in $12.66 \mathrm{mg} / \mathrm{l}-46.20 \mathrm{mg} / \mathrm{l}$ of Cauvery delta region and in $49 \mathrm{mg} / \mathrm{l}-72 \mathrm{mg} / \mathrm{l}$ of Palar region, (Table 4), (Fig 6).

\section{Phosphate}

Nutrient pollution, a form of water pollution, refers to contamination by excessive inputs of nutrients. It is a primary cause of eutrophication of surface waters, in which excess nutrients, usually phosphorus, stimulate algal growth. The Phosphate concentration was recorded in $0.12 \mathrm{mg} / \mathrm{l}-2.40 \mathrm{mg} / \mathrm{l}$ of Cauvery delta region and in $0.98 \mathrm{mg} / \mathrm{l}-.170 \mathrm{mg} / \mathrm{l}$ of Palar region, (Table 4), (Fig 6).

\section{Nitrate}

Nitrate is used mainly in inorganic fertilizers. This is the highest oxidized form of Nitrogen. Nitrate is one of the most common groundwater contaminants in rural areas. It is regulated in drinking water primarily because excess levels can cause methemoglobinemia, or "blue baby" disease. The Nitrate levels of the samples are in the BIS desirable limit, (Table 4), (Fig 6).

\section{Nitrite}

Nitrite in water is due to incomplete oxidation of organic matter containing nitrogen. Nitrite of the samples was found to range from $0.0016 \mathrm{mg} / \mathrm{l}-2.20 \mathrm{mg} / \mathrm{l}$ in Cauvery delta region and in $1.64 \mathrm{mg} / \mathrm{l}-2.51 \mathrm{mg} / \mathrm{l} \mathrm{Palar}$ region, (Table 4), (Fig 6). High concentration of nitrites may cause blue-baby syndrome in children.

\section{Zinc}

Zinc is also present in most drinking water. If drinking water or beverages are stored in metal containers, they may have high levels of zinc. If drinking water flows through pipes coated with zinc to resist rust, zinc could be in that drinking water. Levels of zinc in air are low. Air near factories may have higher levels of zinc. In industry, zinc is used for galvanizing iron and other metals to protect them against rust and corrosion. Mass poisoning has been reported following the drinking of acidic beverages kept in galvanized containers; fever, nausea, vomiting, stomach cramps, and diarrhoea occurred 3-12 h after ingestion. The Zinc concentration of groundwater was found to be ranges from $0.075 \mathrm{mg} / \mathrm{l} 48.53 \mathrm{mg} / \mathrm{l}$ and $20.48 \mathrm{mg} / \mathrm{l}-$ $36.41 \mathrm{mg} / \mathrm{l}$ for groundwater of Cauvery Delta and Palar regions respectively, (Table-4 and 6) Fig-12.

\section{Copper}

Copper concentrations in drinking-water vary widely as a result of variations in water characteristics, such as $\mathrm{pH}$, hardness and copper availability in the distribution system. Too much copper can cause adverse health effects, including vomiting, diarrhea, stomach cramps, and nausea. It has also been associated with liver damage and kidney disease. The Phosphate concentration ranges was recorded in $0.0012 \mathrm{mg} / \mathrm{l}-6.94$ $\mathrm{mg} / \mathrm{l}$ of Cauvery delta region and in $2.20 \mathrm{mg} / \mathrm{l}-5.10 \mathrm{mg} / \mathrm{l}$ of Palar region, (Table 4), (Fig 6).

Iron

In drinking-water supplies, iron salts are unstable and are precipitated as insoluble iron hydroxide, which settles out as a rust-coloured silt. Excess iron can lead to hemochromatosis, a severe disease that can damage the body's organs. Early symptoms include fatigue, weight loss, and joint pain, but if hemochromatosis is not treated, it can lead to heart disease, liver problems and diabetes. A blood test can 
identify iron overload. The Iron concentration was recorded in $0.29 \mathrm{mg} / \mathrm{l}-11.61 \mathrm{mg} / \mathrm{l}$ of Cauvery delta region and in $15.89 \mathrm{mg} / \mathrm{l}-36.50 \mathrm{mg} / \mathrm{l}$ of Palar region, (Table 4), (Fig 6).

\section{Manganese}

In concentrations higher than $0.05 \mathrm{mg} / \mathrm{l}$ the manganese may become noticeable by impairing color, odor, or taste to the water. However, according to the EPA health effects are not a concern until concentrations are approximately 10 times higher. Manganese can be consumed from our diet and in our drinking water. The Manganese concentration was recorded in $0.3 \mathrm{mg} / \mathrm{l}-255 \mathrm{mg} / \mathrm{l}$ of Cauvery delta region and in $1.00 \mathrm{mg} / \mathrm{l}$ $-3.40 \mathrm{mg} / \mathrm{l}$ of Palar region, (Table 4), (Fig 6).

Lead

Homes may have internal plumbing materials containing lead. Since it cannot able to see, taste, or smell lead dissolved in water, testing is the only sure way of telling whether there are harmful quantities of lead in your drinking water. Lead can also be inhaled or sometimes even absorbed through the skin, though lead can't move from water into skin, so it's safe to bathe in lead-contaminated water as long as don't drink it. Once it's in the body, lead competes with calcium to be absorbed by the body. Lead concentrations of samples from Cauvery delta region and Palar region range between $(0.2-6.90) \mathrm{mg} / \mathrm{l}$ and $(4.50-5.20) \mathrm{mg} / \mathrm{l}$ respectively (Table 3 and 5$)$

Table 3(a): Physical Parameters of the ground water collected from Cauvery delta region

\begin{tabular}{|c|c|c|c|c|c|c|c|c|c|c|c|}
\hline Parameters & $\mathbf{S}_{1}$ & $\mathbf{S}_{2}$ & $\mathbf{S}_{3}$ & $\mathbf{S}_{4}$ & $\mathbf{S}_{5}$ & $\mathbf{S}_{6}$ & $\mathbf{S}_{7}$ & $\mathbf{S}_{8}$ & $\mathbf{S}_{9}$ & $\mathbf{S}_{10}$ & $\begin{array}{c}\text { BIS } \\
\text { Desirable } \\
\text { limit }\end{array}$ \\
\hline Taste & Salty & $\begin{array}{c}\text { Taste } \\
\text { less }\end{array}$ & Salty & $\begin{array}{c}\text { Taste } \\
\text { less }\end{array}$ & Salty & $\begin{array}{c}\text { Taste } \\
\text { less }\end{array}$ & $\begin{array}{c}\text { Taste } \\
\text { less }\end{array}$ & Salty & Salty & $\begin{array}{c}\text { Taste } \\
\text { less }\end{array}$ & Agreeable \\
\hline Odour & Less & Less & Less & Less & Less & Less & Less & Less & Less & Less & Agreeable \\
\hline EC(dsm $)^{-1}$ & 0.58 & 2.62 & 2.27 & 1.50 & 0.90 & 1.11 & 1.40 & 2.55 & 4.84 & & \\
\hline TDS(mg/l) & 1120 & 1080 & 947 & 645 & 580 & 493 & 900 & 1638 & 1840 & 616 & $500 m g / l$ \\
\hline Turbidity & 01.3 & 01.2 & 0.10 & 00.9 & 01.0 & 00.8 & 01.1 & 01.2 & 00.7 & 0.8 & 2 NTU \\
\hline
\end{tabular}


Table 3(a): Physical Parameters of the ground water collected from palar region

\begin{tabular}{|c|c|c|c|c|}
\hline Parameters & $S_{1}$ & $\mathrm{~S}_{2}$ & $\mathrm{~S}_{3}$ & BIS Desirable limit \\
\hline Taste & Taste less & Taste less & Taste less & Agreeable \\
\hline Odour & Less & Less & Less & Agreeable \\
\hline $\mathrm{EC}\left(\mathrm{dsm}^{-1}\right)$ & 1.60 & 1.70 & 0.50 & - \\
\hline $\mathrm{TDS}(\mathrm{mg} / \mathrm{l})$ & 1030 & 1088 & 328 & $500 \mathrm{mg} / \mathrm{l}$ \\
\hline Turbidity & 00.9 & 01.4 & 00.6 & 2NTU \\
\hline
\end{tabular}

Table 4(a): Chemical Parameters of the ground water collected from Cauvery delta region

\begin{tabular}{|c|c|c|c|c|c|c|c|c|c|c|c|}
\hline Parameters & $\mathbf{S}_{1}$ & $\mathbf{S}_{2}$ & $\mathbf{S}_{3}$ & $\mathbf{S}_{4}$ & $\mathbf{S}_{5}$ & $\mathbf{S}_{6}$ & $\mathbf{S}_{7}$ & $\mathbf{S}_{8}$ & $\mathbf{S}_{9}$ & $\begin{array}{c}\text { BIS } \\
\text { Desirable } \\
\text { limit }\end{array}$ \\
\hline $\mathrm{P}^{\mathrm{H}}$ & 7.84 & 7.47 & 7.09 & 7.70 & 7.55 & 7.44 & 7.45 & 7.90 & 6.93 & 7.93 & $6.5-8.5$ \\
\hline Chloride & 313.24 & 89.98 & 221.60 & 130.96 & 25 & 93.98 & 39 & 54 & 339.90 & 161.6 & $250 \mathrm{mg} / \mathrm{l}$ \\
\hline Sulphate & 4.9 & 6.7 & 1.6 & 8.2 & 18 & 2.8 & 21 & 35 & 3.4 & 22.8 & $200 \mathrm{mg} / \mathrm{l}$ \\
\hline Calcium & 108.22 & 53.8 & 89.18 & 87.32 & 132 & 64.93 & 172 & 84 & 138.28 & 43.1 & $75 \mathrm{mg} / \mathrm{l}$ \\
\hline
\end{tabular}




\begin{tabular}{|c|c|c|c|c|c|c|c|c|c|c|c|}
\hline Phosphate & 0.12 & 0.95 & 1.06 & 0.45 & 0.80 & 0.4 & 1.20 & 2.40 & 1.17 & & - \\
\hline Nitrate & 3.10 & 2.26 & 2.60 & 2.47 & 18 & 3.22 & 2.9 & 15.40 & 3.45 & 6.77 & $45 \mathrm{mg} / \mathrm{l}$ \\
\hline Nitrite & 0.0016 & 0.0030 & 0.2 & 0.0026 & 1.50 & 0.0012 & 2.20 & 1.50 & 0.0119 & 0.0035 & $0.02 \mathrm{mg} / \mathrm{l}$ \\
\hline Zinc & 43.41 & 48.53 & 26.47 & 23.63 & 22.87 & 18.72 & 1.57 & 23.07 & 12.41 & 0.075 & $5 \mathrm{mg} / \mathrm{l}$ \\
\hline Copper & BDL & 0.044 & 0.004 & 0.49 & 0.90 & 0.0012 & 6.94 & 2.80 & BDL & 0.87 & $0.05 \mathrm{mg} / \mathrm{l}$ \\
\hline Iron & 0.29 & 0.32 & 0.38 & 0.33 & 11.61 & 0.36 & 37.39 & $15 \cdot 40$ & 0.46 & 0.191 & $0.3 \mathrm{mg} / \mathrm{l}$ \\
\hline Manganese & 0.3 & BDL & 14.61 & - & - & BDL & 255.00 & 2.90 & BDL & BDL & $0.1 \mathrm{mg} / \mathrm{l}$ \\
\hline Lead & 0.2 & 0.3 & 0.2 & 0.29 & 3.40 & 2.84 & 2.60 & 6.90 & 1.81 & 0.21 & $0.01 \mathrm{mg} / \mathrm{l}$ \\
\hline
\end{tabular}

Table 4(b): Chemical Parameters of the ground water collected from Palar region

\begin{tabular}{|c|c|c|c|c|}
\hline Parameters & $\mathbf{S}_{1}$ & $\mathbf{S}_{2}$ & $\mathbf{S}_{3}$ & BIS Desirable limit \\
\hline $\mathrm{P}^{\mathrm{H}}$ & 6.66 & 5.26 & 8.02 & $6.5-8.5$ \\
\hline Chloride & 48 & 45 & 20 & $250 \mathrm{mg} / \mathrm{l}$ \\
\hline Sulphate & 28 & 24 & 10.30 & $200 \mathrm{mg} / \mathrm{l}$ \\
\hline Calcium & 187 & 176 & 62 & $75 \mathrm{mg} / \mathrm{l}$ \\
& & & & \\
\hline
\end{tabular}




\begin{tabular}{|c|c|c|c|c|}
\hline Magnesium & 72 & 68 & 49 & $30 \mathrm{mg} / \mathrm{l}$ \\
\hline Phosphate & 1.20 & 1.70 & 0.98 & - \\
\hline Nitrate & 36 & 32 & 26.40 & $45 \mathrm{mg} / \mathrm{l}$ \\
\hline Nitrite & 2.30 & 2.51 & 1.64 & $0.02 \mathrm{mg} / \mathrm{l}$ \\
\hline Zinc & 36.41 & - & 20.48 & $5 \mathrm{mg} / \mathrm{l}$ \\
\hline Copper & 2.20 & - & 5.10 & $0.05 \mathrm{mg} / \mathrm{l}$ \\
\hline Iron & 15.89 & 36.50 & 18.40 & $0.3 \mathrm{mg} / \mathrm{l}$ \\
\hline Manganese & 1.00 & - & 3.40 & $0.1 \mathrm{mg} / \mathrm{l}$ \\
\hline Lead & $4 \cdot 50$ & 5.20 & 4.80 & $0.01 \mathrm{mg} / \mathrm{l}$ \\
\hline
\end{tabular}


The graphical representation of the physicochemical parameter variation of the study areas are given below:

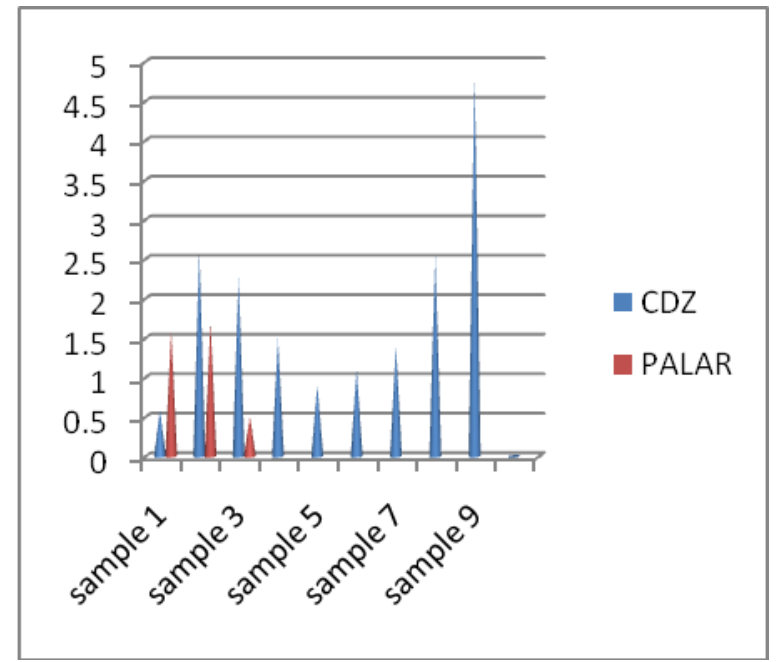

Figure 1: EC variation of the study area

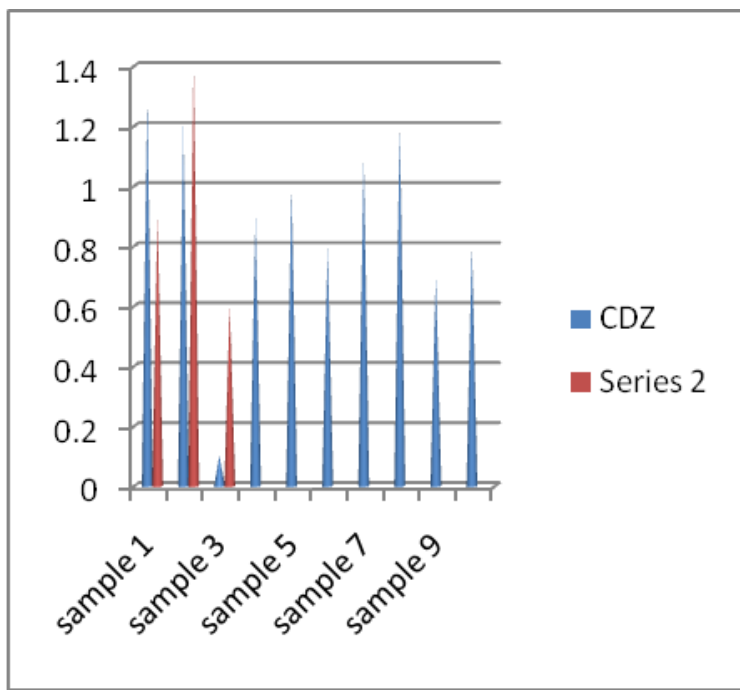

Figure 3: Turbidity variation of the study area

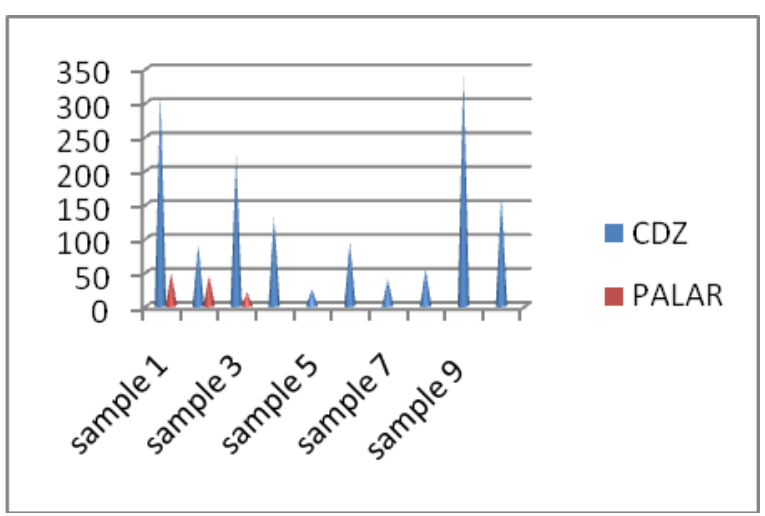

Figure 5: chloride variation of the study area

http://dx.doi.org/10.19085/journal.sijmas031201

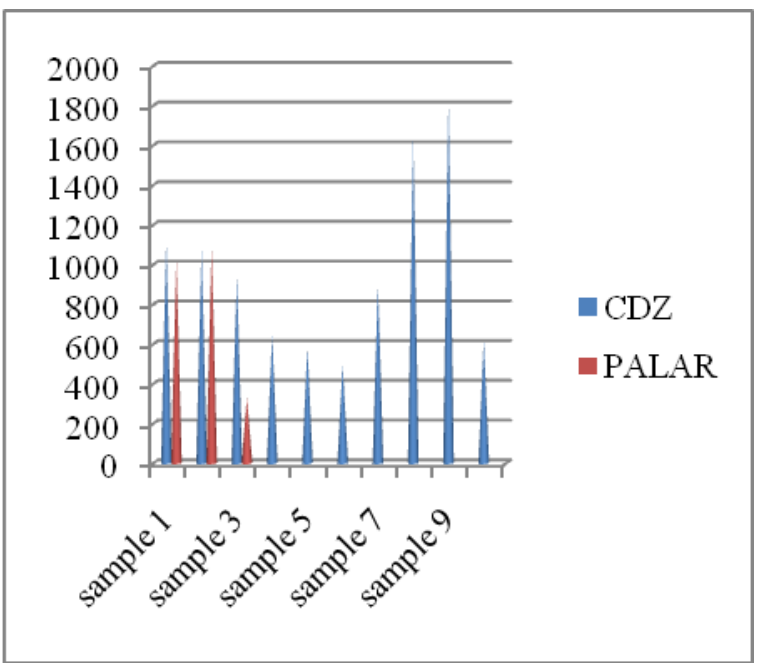

Figure 2: TDS variation of the study area

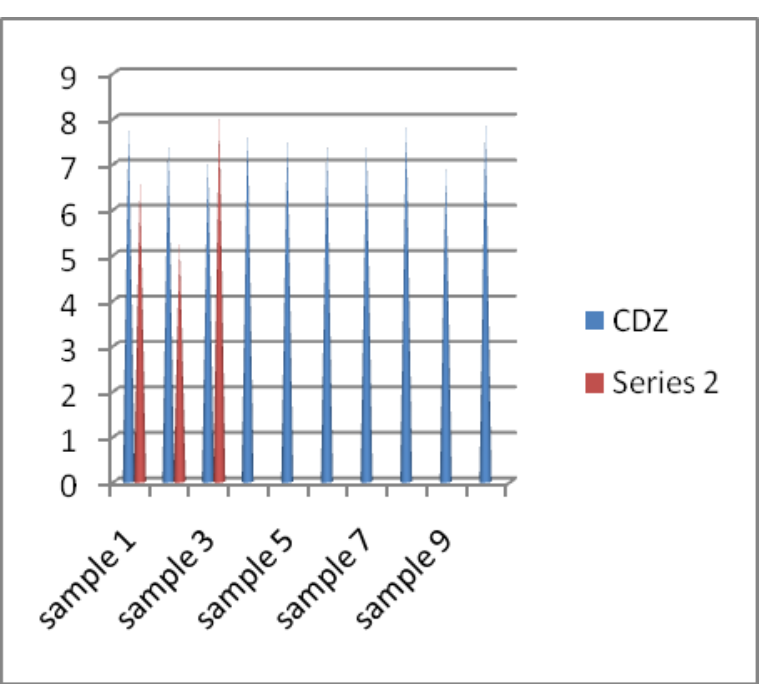

Figure 4: Turbidity variation of the study area

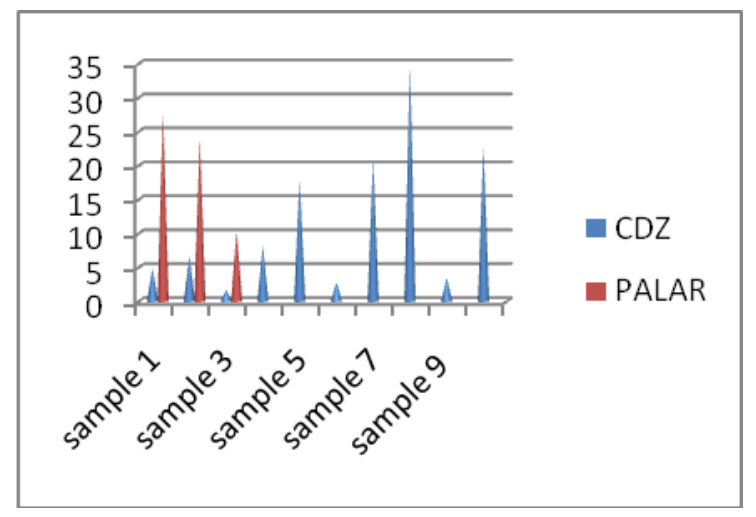

Figure 6: sulphate variation of the study area 


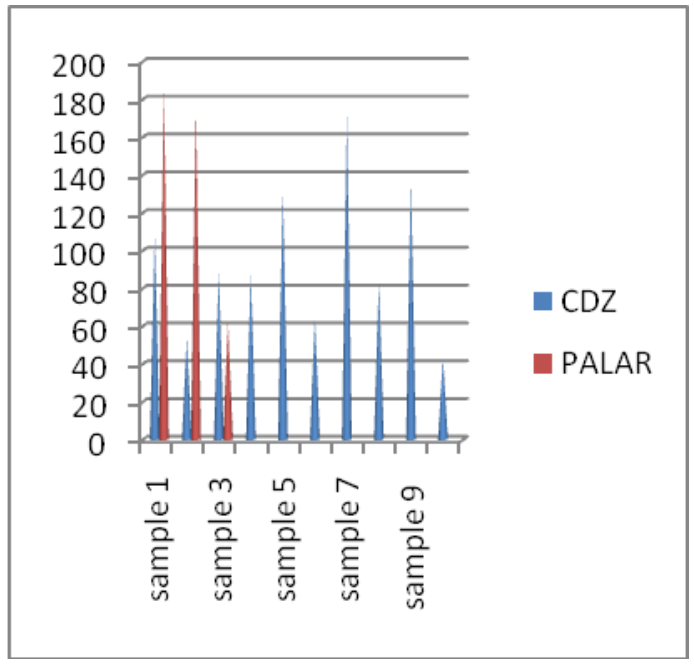

Figure 7: Calcium variation of the study area

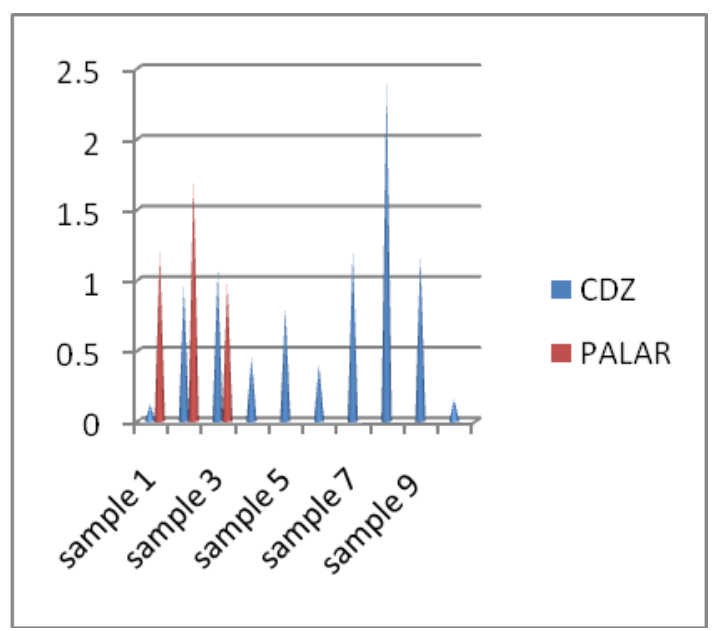

Figure 9: Phosphate variation of the study area

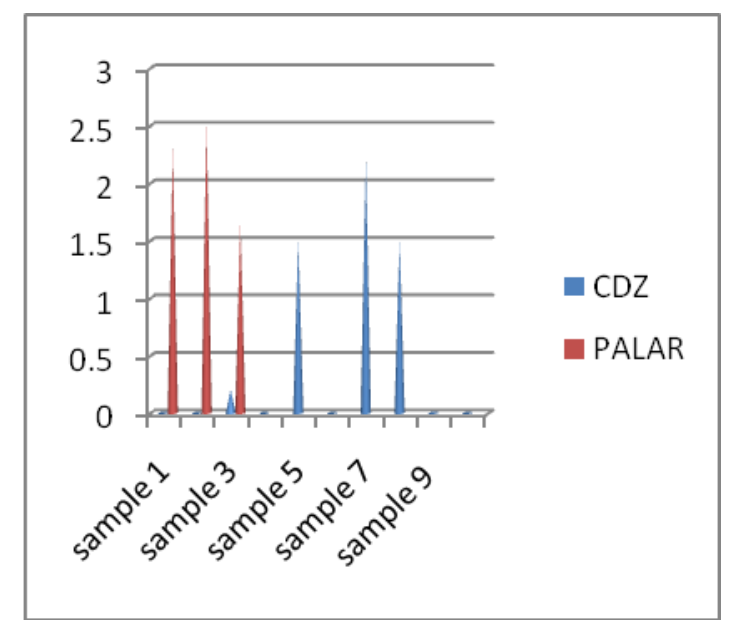

Figure 11: Nitrite variation of the study area

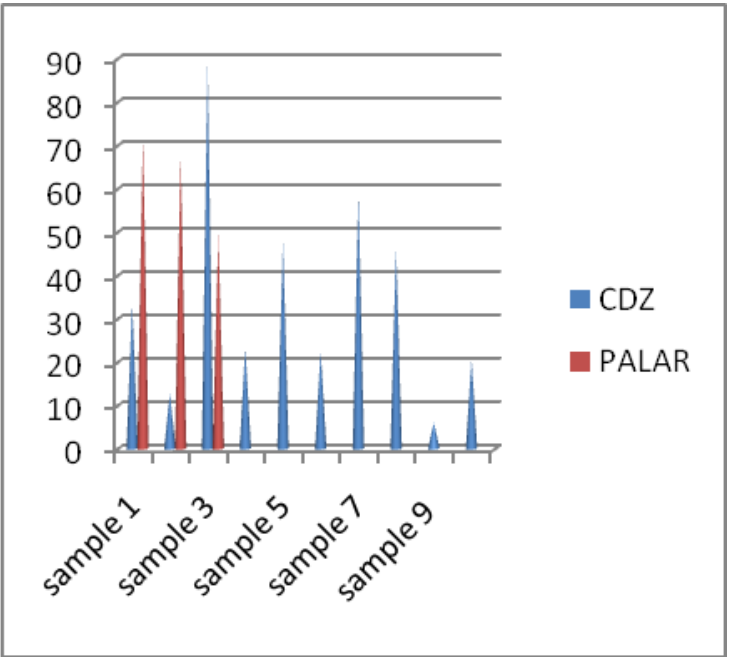

Figure 8: Magnesium variation of the study area

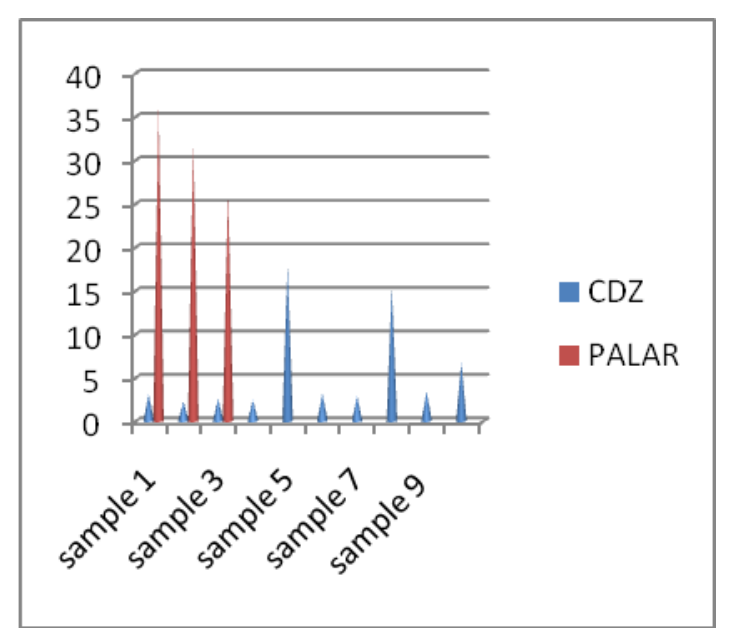

Figure 10: Nitrate variation of the study area

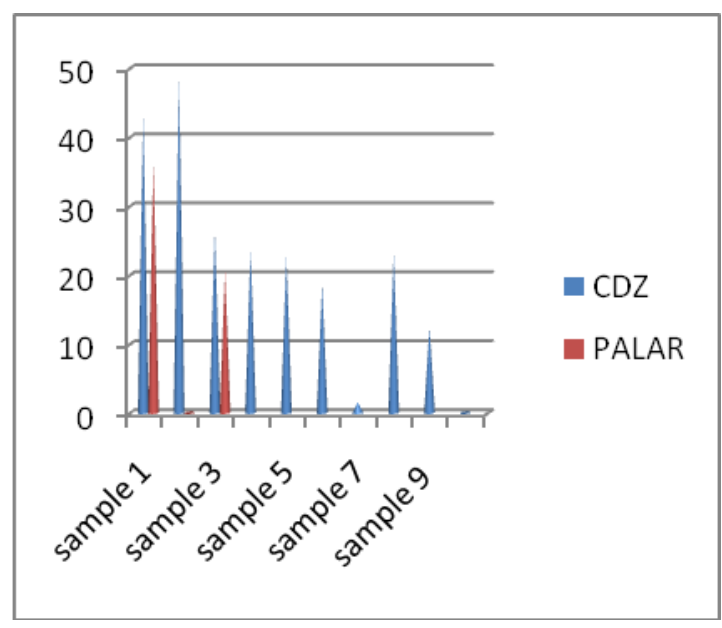

Figure 12: Zinc variation of the study area 


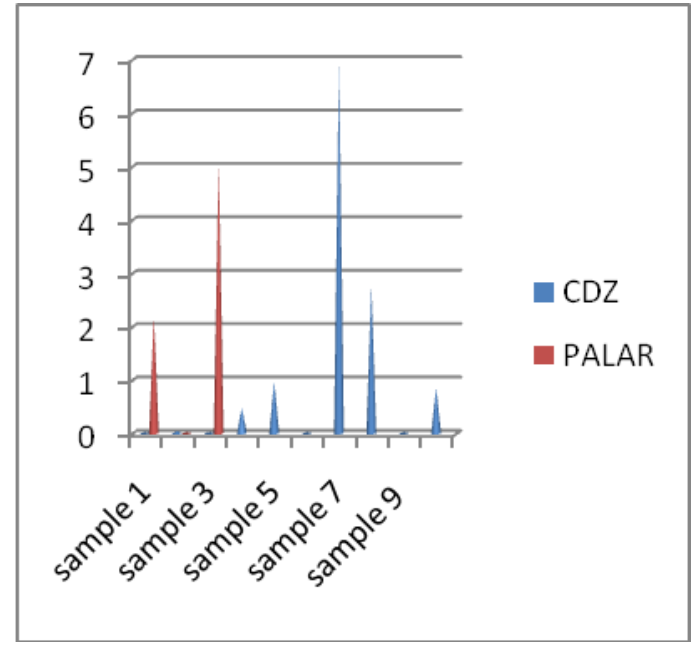

Figure 13: Copper variation of the study area

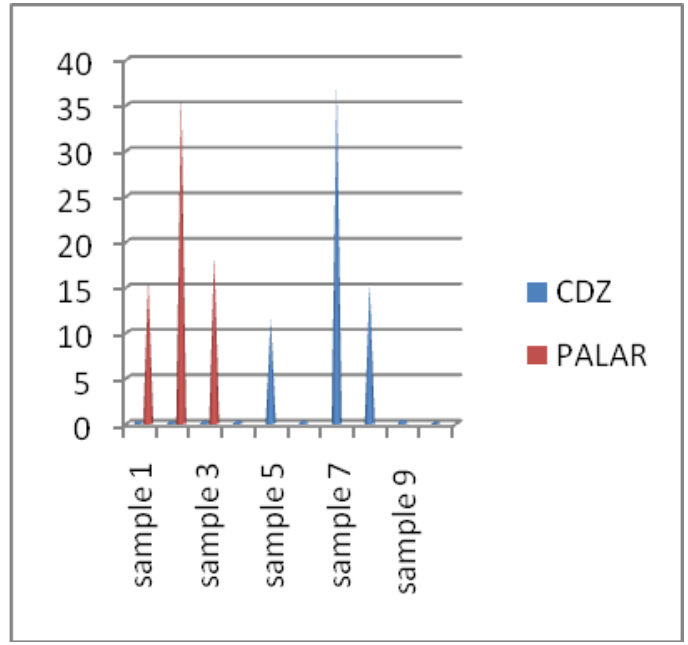

Figure 14: Iron variation of the study area

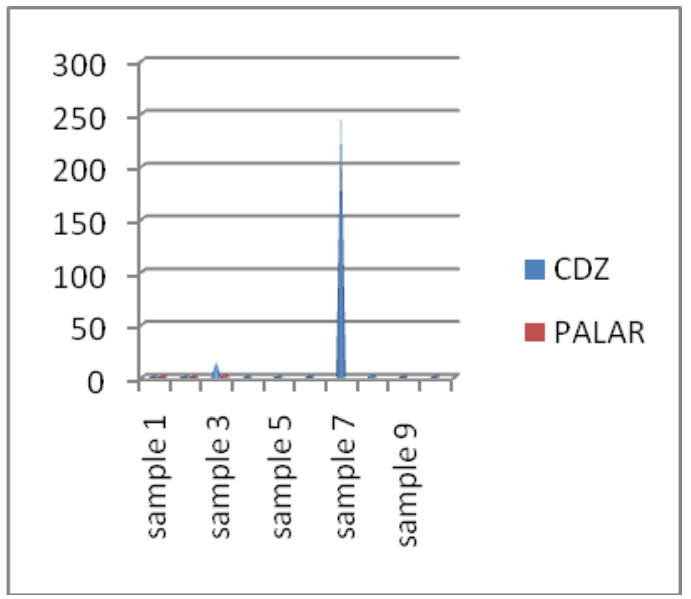

Figure 15: Manganese variation of the study area

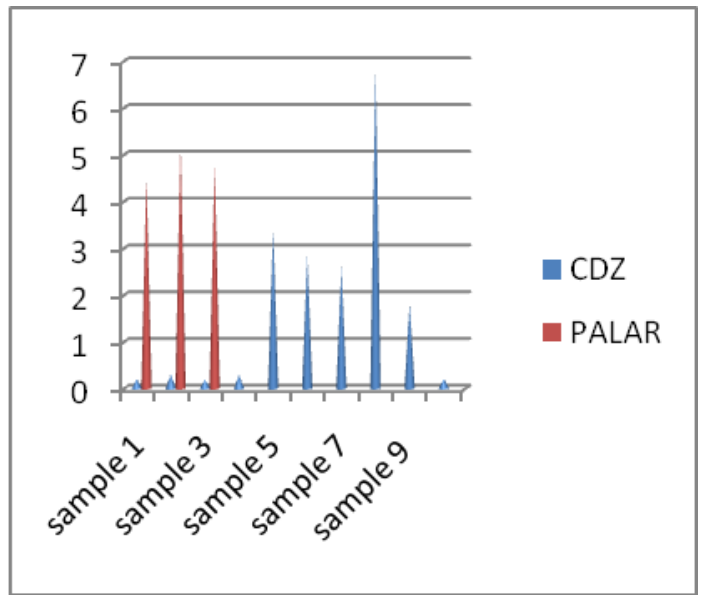

Figure 16: Lead variation of the study area

\subsection{Findings}

- The taste of ground water sample number $\mathrm{S}_{1}, \mathrm{~S}_{3}, \mathrm{~S}_{5}, \mathrm{~S}_{8}$ and $\mathrm{S}_{9}$ is salty in the Cauvery delta region.

- The entire collected samples in the Cauvery delta region and Palar region had lying in a agreeable odour.

- The entire samples had high Total dissolved substances of ground water and except sample number $S_{6}$ had low in Cauvery delta region and sample number $S_{1}$, and $S_{2}$ is high in Palar region.

- The Turbidity and $\mathrm{p}^{\mathrm{H}}$ content of ground water samples was found to be within the BIS describe limit.

- In Cauvery delta region sample $S_{5}$ had low chloride level and sample $S_{1}$ had high level compared with the BIS agreeable limit. In Palar region all the collected samples had low level of chloride concentration.

- The sulphate content of ground water samples was found to be within the BIS describe limit. 
- The Calcium content of sample number $S_{9}$ from Cauvery delta region and $S_{1}$ from Palar region is above the desirable limit.

- The Magnesium content of sample number $S_{3}$ from Cauvery delta region and $S_{1}$ from Palar region is above the desirable limit.

- The Nitrate concentration of ground water samples was found to be within the BIS describe limit.

- The Nitrite concentration of sample number $S_{7}$ from Cauvery delta region and $S_{2}$ from Palar region is above the desirable limit.

- The Zinc concentration of sample number $S_{7}$ and $S_{10}$ in the Cauvery delta region had lying the desirable limit other samples had above the desirable limit. The sample number $S_{1}$ and $S_{3}$ had high level and $\mathrm{S}_{2}$ had below detection level.

- The Copper concentration of sample number $S_{7}$ from Cauvery delta region and $S_{3}$ from Palar region is very high to the desirable limit.

- The Iron concentration of sample number $\mathrm{S}_{5}$ from Cauvery delta region and $\mathrm{S}_{2}$ from Palar region is very high to the desirable limit.

- The Manganese concentration of sample number $S_{7}$ from Cauvery delta region and $S_{3}$ from Palar region is very high to the desirable limit.

- The Lead concentration of entire collected samples in the Cauvery delta region and Palar region had very high level to desirable limit.

\subsection{Recommendations}

To ensure the better quality of ground water, attention need to be paid to the following efforts:

- Identify industrial units that are the biggest polluters of river water. If NEQS regarding wastewater were strictly enforced, these industries would have to reduce and treat their waste water before disposal.

- Provide government help for waste management by industries.

- A regular investigation of qualitative and quantitative monitoring of water resources.

- Construct proper sanitary landfill sites.

- Throw refuse into garbage cans. Visitors who throw garbage into pools, lakes, ponds, and even along the beaches pollute recreational sites on a daily basis. This not only pollutes the water but also mars the beauty of the site.

- Dispose of unwanted paints or oils carefully. They should not be thrown into drains or sewers.

- Conserve water at home and at workplace, rather than waste it.

- Boil or filter drinking water to eliminate disease-causing bacteria.

- Reduce ONGC's and Methane coal project schemes in agricultural areas.

- Rain water harvesting is the one of the solution to minimize the heavy metals concentration in drinking water.

- Conducting epidemiological study in the areas close to contaminated water bodies will help to assess the effects of polluted water on the health of consumers.

- Participate in awareness-raising activities. Students can be a great help in this regard.

\section{Conclusion}

This work has presented the levels of physicochemical parameters in water samples collected from Cauvery delta region and Palar region. The results revealed that there was an indication of some physicochemical pollution in the bodies of water although some values of these parameters are within 
acceptable range but not at all. The study further revealed that the water is not safe for drinking but suitable for aquatic life and also for irrigation purpose in some extend. The human beings of that polluted region are suffering with various diseases like gastro intestinal irritations, skin irritation, vomiting, dehydration, liver damage, renal damage, impaired neurological and motor development, etc., Hence, suggested to take proper care and Action should be taken by the Government to prevent the ground and surface water bodies.

\section{References}

1. Natarajan Venkat Kumar, Samson Mathew, Ganapathiram Swaminathan, "Analysis of Groundwater for Potability from Tiruchirappalli City Using Backpropagation ANN Model and GIS", Journal of Environmental Protection, 2010, 1, 136-142.

2. D. Kannan, N. Mani and S. Thiyagarajan, "Chemical analysis of ground water from various parts of Thiruvarur andNagapattinam district, Tamilnadu, India", Pelagia ResearchLibrary,Der Chemica Sinica, 2014, 5(3):83-91.

3. R M Yuvaraj \& Dr. M. Rajeswari, "Continentality and Rainfall over CauveryDelta Region of Tamil Nadu", Imperial Journal of Interdisciplinary Research (IJIR) Vol-2, Issue-6, 2016.

4. Chittaranjan Ray and Ravi Jain, "Drinking Water Treatment Technology-Comparative Analysis".

5. Muthukumar S, Lakshumanan C, Santhiya G, Krishnakumar P, Viveganandann S, "Assessment of water quality in Trichy City, Tamil Nadu, India", International Journal Of Environmental Sciences Volume 1, No 7, 2011.

6. K.Rajalakshmi, G.Bhaskaran, K.Gobinath, " Assessment Of Ground Water Quality In Vellore District, Tamil Nadu, India A Geospatial Approach", Academy of Agriculture Journal 1: 2 April (2016) 31 - 34.

7. Geetha. A M. Maria Berjilia And N. Vijayalakshmi, "Evaluation Of Ground Water Quality In And Around Ariyalur District, Tamil Nadu - A Statistical Approach", Jr. of Industrial Pollution Control 25 (2) (2009) pp 169-173.

8. Abida Begum, M. Ramaiah§, Harikrishna, Irfanulla Khan And K.Veena. "Heavy Metal Pollution and Chemical Profile of Cauvery River Water”, ISSN: 0973-4945; CODEN ECJHAO E-Journal of Chemistry, http://www.e-journals.net 2009, 6(1), 47-52.

9. František Kožíšek, M.D., Ph.D., "Health significance of drinking water calcium and magnesium”, National Institute of Public Health, February 2003.

10. Background document for development of WHO Guidelines for Drinking-water Quality, "Copper in Drinking-water".

11. S. Dhanakumar1, U. Mani2, R.C. Murthy2, M. Veeramani1, R. Mohanraj, " Heavy Metals And Their Fractionation Profile In Surface Sediments Of Upper Reaches In The Cauvery River Delta, India", International Journal of Geology, Earth and Environmental Sciences ISSN: 2277-2081 (Online)

12. Background document for development of WHO Guidelines for Drinking-water Quality, "Iron in Drinking-water".

13. Background document for development of WHO Guidelines for Drinking-water Quality, "Calcium and magnesium in Drinking-water". 
14. Background document for development of WHO Guidelines for Drinking-water Quality, "Hydrogen ion concentration in Drinking-water".

15. Background document for development of WHO Guidelines for Drinking-water Quality, “ Turbidity in Drinking-water".

16. Background document for development of WHO Guidelines for Drinking-water Quality, "TDS in Drinking-water".

17. Background document for development of WHO Guidelines for Drinking-water Quality, "Zinc in Drinking-water".

18. Background document for development of WHO Guidelines for Drinking-water Quality, "Lead in Drinking-water".

19. Background document for development of WHO Guidelines for Drinking-water Quality, "Nitrate and Nitrogen in Drinking-water".

20. Background document for development of WHO Guidelines for Drinking-water Quality, "Manganese in Drinking-water".

21. Background document for development of WHO Guidelines for Drinking-water Quality, "Chloride in Drinking-water".

22. Background document for development of WHO Guidelines for Drinking-water Quality, "Magnesium in Drinking-water". 